\title{
Wypracowania szkolne $(1945-1946)$ o tematyce wojennej
}

Wartościowym materiałem o charakterze (ego)dokumentalnym, odzwierciedlającym przeżycia młodych Polaków w czasie drugiej wojny światowej, są wypracowania szkolne pisane przez uczniów z Wielkopolski (1945) i Kielecczyzny (1946) ${ }^{1}$. Pochodzą one z Archiwum Instytutu Zachodniego w Poznaniu oraz z Archiwum Państwowego w Kielcach. Pierwszy korpus liczy 184 karty wypracowań, natomiast drugi 1210 oraz 76 rysunków przedstawiających typowe sceny wojny i okupacji. Wielkopolska kolekcja zawiera teksty pisane przez uczniów szkół powszechnych oraz średnich w Kępnie, Krotoszynie, Obrze, Poznaniu, Puszczykowie, Swarzędzu i w Szamotułach, kielecka - wypracowania z kilkudziesięciu szkół powszechnych ówczesnego Szkolnego Okręgu Kieleckiego, m.in. z Bobrzy, Dąbrowy, Iłży, Masłowa, Kielc, Radomia, Skarżyska-Kamiennej, Starachowic, Suchedniowa, Suskowoli, Zwolenia.

Pobieżną charakterystykę wypracowań uczniów szkół wielkopolskich przedstawili na łamach Documenta Occupationis Teutonicae Zdzisław Grot oraz Wincenty (1945-1946) na temat Il wojny światowej, która zostanie wydana w Wydawnictwie Naukowym UMK.

${ }^{1}$ Należy dodać, że kilkaset wypracowań i rysunków nadesłanych na ogólnopolski konkurs organizowany przez władze oświatowe jest przechowywanych w Archiwum Akt Nowych w Warszawie. Cześsciowo materiał ten prezentuje popularna książka Woina w oczach dziecka (pod red. K. Iwanickiej i M. Dubasa, oprac. graf. P. Woźniak, wyd. 1, Warszawa 1983). Autorzy przedstawili w niej głównie rysunki, a w niewielkim wyborze fragmenty wypracowań. Zarówno rysunki, jaki teksty były pokłosiem ogólnopolskiego konkursu ogłoszonego przez ówczesne Ministerstwo Oświaty. 
Ostrowski ${ }^{2}$. Według autorów publikacji inicjatorem pisania wypracowań na temat wojny i okupacji w Wielkopolsce był Karol Strzałkowski, kurator Okręgu Szkolnego Poznańskiego, instrukcja pisania tekstów została natomiast opracowana przez środowisko akademickie Uniwersytetu im. Adama Mickiewicza w Poznaniu³.

Do tej pory oba zbiory, mimo publikacji Grota i Ostrowskiego, nie zostały skutecznie włączone do dyskursów historycznego, socjologicznego, literaturoznawczego i studiów nad dzieciństwem. Należą one do tego samego rodzaju (ego)dokumentów, co dzienniki, pamiętniki i spisane relacje żydowskich dzieci. O ile ostatnie z wymienionych tekstów były przedmiotem badań w Polsce i za granicą, o tyle w wypadku wypracowań sprawa przedstawia się odmiennie. Przyczyną tego stanu rzeczy może być to, że żydowskie świadectwa traktuje się jako zapis autentycznych przeżyć związanych z Holokaustem, wypracowania szkolne ze względu na swoją - jak się powszechnie sądzi - schematyczną formę oraz okoliczności ich tworzenia postrzegane są zaś jako dokumenty (egodokumenty) mniejszej wartości. To prawda, że oba korpusy, wielkopolski i kielecki, powstały z inicjatywy władz oświatowych oraz składające się nań teksty mają formę pisemnego ćwiczenia. Niemniej jednak wypracowania te powinny być czytane przede wszystkim całościowo, a więc jako zapis doświadczenia wojennego Polaków urodzonych między 1926 a 1935 rokiem oraz jako świadectwo kształtowania się wśród nich pamięci zbiorowej ${ }^{4}$ czy, odwołując się do ustaleń Petera L. Bergera i Thomasa Luckmanna, „zestalenia intersubiektywnego"s. Warto posłużyć się tym terminem w odniesieniu do wypracowań szkolnych choćby dlatego, że stanowią one materialną postać ponadjednostkowego doświadczenia i wiedzy na temat życia codziennego najpierw w czasie wojny, a potem okupacji. Są zapisem systemu znakowego, który stał się przedmiotem pokoleniowej wymiany:

Kiedy jakaś liczba jednostek dzieli wspólną biografię, której doświadczenia stają się częścią wspólnego zasobu wiedzy, występuje również zestalenie intersubiektywne. Zestalenie intersubiektywne można uznać za prawdziwie społeczne dopiero wtedy, kiedy zostaje ono zobiektywizowane w postaci takiego lub innego systemu znakowego, to znaczy, kiedy powstaje możliwość powtarzalnej obiektywizacji wspólnych doświadczeń. Dopiero wtedy może dojść do przekazania tych doświadczeń przez jedno pokolenie pokoleniu następnemu albo przez jedną zbiorowość innej zbiorowości ${ }^{6}$.

Z treści wypracowań wynika, że młodzi autorzy dzielili się w nich swoimi przeżyciami, będącymi w wielu wypadkach wciąż boleśnie odciskającym się na ich życiu ciągiem dramatycznych zdarzeń, wśród których najczęściej powtarzały się: utrata bliskich, przemoc ze strony okupanta, aresztowanie i śmierć nauczyciela prowadzącego tajne nauczanie, wysiedlenie, tułaczka i głód. $Z$ badawczego punktu widzenia nie mniej interesujące

2 Documenta Occupationis Teutonicae. III. Wspomnienia młodzieży wielkopolskiej z lat okupacji niemieckiej 1939-1945, oprac. Z. Grot, W. Ostrowski, Poznań 1946.

${ }^{3}$ Ibidem, s. 11. Grot i Ostrowski w Przedmowie do tomu wymienili prof. dr. Jana Rutkowskiego jako głównego autora instrukcji przeznaczonej dla kierowników szkół i nauczycieli.

${ }^{4}$ B. Szacka, Czas przeszły, pamięć, mit, Warszawa 2006. Autorka w swojej definicji pamięci zbiorowej podkreśla jej dynamiczny charakter i podatność na różnego rodzaju przekształcenia. Należy dodać, że w wypadku dzieci, które w chwili wybuchu wojny miały od 4 do 14 lat, sposób zapamiętywania, a potem selekcjonowania i porządkowania poszczególnych zdarzeń oparty był przede wszystkim na silnych emocjach.

${ }^{5}$ P. L. Berger, T. Luckmann, Społeczne tworzenie rzeczywistości. Traktat z socjologii wiedzy, przeł. i przedmowa J. Niżnik, wyd. 2, Warszawa 2010

${ }^{6}$ Ibidem, s. 100.

Sztuka Edycji 2/2020 
Wypracowania nie mają jednolitej struktury i przez młodych ludzi ten sam temat był realizowany w odmienny sposób jest to, czego w uczniowskich tekstach nie ma, a co z pewnością było elementem ich codzienności i w sposób bezpośredni wiązało się z okupacją.

Dyskutowane wypracowania stanowią obszerny i zróżnicowany jakościowo korpus, który można podzielić na dwie części. Pierwsza to zbiór osobistych wypowiedzi na następujące tematy: „Najbardziej pamiętna dla mnie chwila w czasie okupacji niemieckiej”, „Moje wspomnienia z czasów okupacji” i „Wspomnienia z tajnego nauczania”. Drugą zaś tworzą wypracowania zawierające przede wszystkim ogólne refleksje o drugiej wojnie światowej, choć i tu niektórzy uczniowie pisali o własnych doświadczeniach związanych z okrucieństwem okupanta zarówno wobec ludności cywilnej, jak i żołnierzy, powstańców warszawskich oraz partyzantów. Na Kielecczyźnie nastolatkowie tworzyli teksty na temat „O czym mówią zbiorowe mogiły”, w Wielkopolsce kilkoro uczniów ze szkół ponadpodstawowych opracowało natomiast zagadnienie „O martyrologii matki i dziecka podczas okupacji niemieckiej”. Gdy sprawę tematyki analizowanych wypracowań ująć ogólnie, należy powiedzieć, że dominowały w nich wydarzenia lokalne i bezpośrednio związane z mniej lub bardziej tragicznymi losami rodziców ich autorów, starszego rodzeństwa i krewnych, sąsiadów. Mniej miejsca zajmują w nich sprawy o ogólnopolskim zasięgu, które - jak można z dużym prawdopodobieństwem założyć - były efektem działań edukacyjnych nauczyciela. Najchętniej młodzi ludzie pisali na trzy tematy: „Chwila dla mnie najbardziej pamiętna z czasów okupacji”, „Moje wspomnienia z czasów okupacji” i „Wspomnienie zbrodni niemieckiej”. Nieco mniejszą popularnością cieszyły się zagadnienia: „Co mówią zbiorowe mogiły”, „Wspomnienie z tajnego nauczania” oraz „Moje wspomnienie ze szkoły z czasów niemieckich”.

Wypracowania nie mają jednolitej struktury i przez młodych ludzi ten sam temat był realizowany w odmienny sposób, odznaczają się one jednak typowymi dla szkolnych tekstów cechami, jak oficjalny ton wypowiedzi, względnie poprawna stylistyka, zazwyczaj zamknięta, trójdzielna kompozycja. Ostatni element nie dotyczy krótkich tekstów. Wymienione właściwości nie stoją w sprzeczności z bezpośredniością, szczerością, a także intymnością uczniowskich wypowiedzi, gdyż młodzi ludzie płynnie przechodzili między stylem oficjalnym a zwierzeniowym i nawet familiarnym, między narracją podporządkowaną strukturze opowieści pisanej a narracją mówioną, którą należy włączyć do oral history. To prawda, że dyskutowane teksty mają materialną postać rękopiśmiennego wypracowania, ale zarazem noszą cechy opowieści ustnej, co związane jest z okolicznościami ich powstania.

W dawno temu opowiadanych historiach wojna zajmowała pewnie niepoślednie miejsce. Podobnie jak w toczonych kiedyś i teraz nieformalnych rozmowach rodzinnych, sąsiedzkich i wszelkich innych, które dotyczą przeszłości. Obie te odmiany narracji bywają nazywane historią mówioną (oral history). Niekiedy - raczej w skrajnym ujęciu - termin ten jest odnoszony także do zbiorów pisemnych relacji dotyczących przeszłości, tworzonych na „zamówienie”. Zamawiającymi, czy raczej wywołującymi te źródła, są badacze życia społecznego: zwykle historycy społeczni lub socjologowie?

P. Filipkowski, Historia mówiona i wojna, w: Wojna. Doświadczenie i zapis. Nowe źródła, problemy, metody badawcze, pod red. S. Buryły i P. Rodaka, Kraków 2006, s. 13. 
Omawiane teksty powstały na zamówienie polskich władz oświatowych i - poza korpusem wielkopolskim, a więc stosunkowo nielicznym - nigdy nie zostały zbadane pod kątem doświadczeń dzieci związanych z wojną. Nie zmienia to jednak stanu rzeczy, że mamy do czynienia z wartościowym materiałem. Ponadto wiele wypracowań wyróżnia się ozdobnym - niekiedy poetyckim - językiem oraz dużą artystyczną ekspresją. Zgromadzony zbiór wypracowań pisanych w latach 1945-1946 to zapis doświadczenia młodych Polaków, którzy w 1939 roku mieli od 4 do 14 lat, a zatem mniej lub bardziej świadomie przeżywali działania wojenne, a potem hitlerowską okupację. Ich wiarygodność jako świadków i uczestników nie może być zrównana z osobami dojrzałymi, dysponującymi większym doświadczeniem i bardziej rozległą ogólną wiedzą, co nie osłabia znaczenia wspomnieniowego tekstu w badaniach historycznych, socjologicznych, literaturoznawczych i kulturoznawczych.

Lektura obszernego korpusu wypracowań utwierdza w przekonaniu, że ograniczona wiekiem, a zatem i doświadczeniem, perspektywa opisu wojny nie osłabia ich dokumentalnej wartości. Stanowią one głos pokolenia, którego dzieciństwo przypadło na okres 1939-1945, a zarazem jego członkowie - dziewczynki i chłopcy - potrafili przełamać barierę milczenia i w mniej lub bardziej udany sposób opowiedzieć za pomocą tekstu o własnych przeżyciach. Okoliczności szkolne oraz to, że pisanie wypracowań związane było z ogólnopolską akcją nadzorowaną przez ministerstwo (nie dotyczy to 99 tekstów z Wielkopolski, tworzonych między majem a wrześniem 1945 roku), wyznacza sposób badawczego postępowania. Otóż metaforycznie należałoby sprawę ująć w ten sposób, że mamy do czynienia z osobistymi dokumentami „skażonymi” warunkami, w których powstały. Lektura kilkuset wypracowań uświadamia fakt niebagatelny, że zazwyczaj ich pisanie - choć niekoniecznie było to regułą - zostało poprzedzone lekcją lub cyklem lekcji. Najpierw zatem młodzi ludzie opowiadali o swoich doświadczeniach związanych z okresem 1939-1945, a następnie zapisywali je (lub przedstawiali w formie rysunków), co pozwala traktować omawiane teksty jako (auto)zapis oral history. Z dużym prawdopodobieństwem należy założyć, że umożliwiało to nauczycielom odpowiednie modelowanie obrazu wojennych przeżyć uczniów; nie sądzę jednak, by działania pedagoga miały charakter indoktrynacji albo zideologizowanej perswazji służącej przekonaniu młodych ludzi do przyjęcia argumentów „oficjalnych”, aprobowanych przez ówczesne władze na temat przebiegu drugiej wojny światowej.

Warto zatem odnotować owe miejsca „skażenia”; niemal we wszystkich wypracowaniach uczniowie przypisują ZSRR oraz Armii Czerwonej wyłącznie pozytywną rolę w działaniach wojennych, tabuizują wrogość wielu Polaków, w tym dzieci, wobec Żydów oraz przypisują zbrodnię katyńską nazistom. To najbardziej rzucające się w oczy miejsca „skażone”, które niekoniecznie muszą potwierdzać prawdziwe doświadczenia wszystkich autorów biorących udział w konkursie na wspomnienia wojenne. Na przykład w kilkunastu tekstach pojawia się informacja o Polakach, którzy donosili Niemcom na swoich sąsiadów, pomagających partyzantom oraz zdradzali policji granatowej (Polnische Polizei im Generalgouvernement) lub nazistom miejsca ukrywających się

${ }^{8}$ Jednym z pierwszych psychologicznych studiów poświęconych temu, jak konkretne działania wojenne (bombardowanie, separacja od rodziców, ewakuacja) wpływają na dzieci, jest książka Anny Freud i Dorothy T. Burlingham War and Children z 1943 roku. Szczególnie cenna jest druga część owego psychologicznego studium, w którym prezentowane są wypowiedzi młodych Anglików. Ze zgromadzonego dokumentalnego materiału wynika, że trzyletnie dzieci rozpoznawały nadlatujące nad miasta niemieckie bombowce i potrafiły wyrobić w sobie nawyk wychodzenia z domu do schronu. Autorki ponadto dowodziły, że we wczesnym dzieciństwie człowiek dobrze zapamiętuje szczegóły związane z wojennymi doświadczeniami. 
Żydów. O ile wiedza młodych ludzi na temat zbrodni katyńskiej mogła być czerpana z oficjalnych przekazów, o tyle postępowanie żołnierzy Armii Czerwonej wobec ludności cywilnej - w tym kobiet - trudno było ukryć lub zignorować. W zaledwie kilku wypracowaniach pojawiają się informacje, które mogłyby wskazywać na strach - mniejszy bądź większy - przed czerwonoarmistami.

Zapis dziecięcych doświadczeń wojennych, mających formę szkolnych wypracowań, to - mimo „skażenia” - cenne źródło informacji o tym przede wszystkim, jak wyglądała codzienność młodych Polaków między 1939 a 1945 rokiem oraz w jaki sposób przeżywali wojenną traumę. Tabuizacja i przemilczenia w analizowanych tekstach pozwalają zrozumieć złożoność relacji między Polakami a Żydami, ale także i wewnątrz lokalnych społeczności. Obecne w wypracowaniach spojrzenie na Zagładę odznacza się z jednej strony szczerym współczuciem, a z drugiej zaś dziecięcy autorzy dostrzegali pewną wspólnotę doświadczeń.

Opisane w wypracowaniach wojenne historie są przez młodych ludzi przeżyte, ale zdarzają się teksty, w których autorzy dzielą się opowieściami zasłyszanymi od rówieśników bądź osób starszych. W pierwszym wypadku dominuje warstwa ekspresyjna wypowiedzi, kompozycja ma charakter bardziej luźny, ton podobny jest - poza wstępnym i końcowym akapitem - do zwierzenia często połączonego z wyrażaną wprost niechęcią do okupanta. Wypracowania przedstawiające wydarzenia związane z innymi osobami charakteryzują się natomiast większą spójnością, oszczędnością użycia waloryzujących określeń, choć i tu wielu uczniów na końcu donosi o swojej głębokiej niechęci do Niemców oraz o radości z pokonania wroga.

Głos pokolenia utrwalony w wypracowaniach, a więc w tekstach służących kształceniu umiejętności komunikacyjnych, jest względnie różnorodny, gdy weźmiemy pod uwagę sposób prezentowania wypadków lat 1939-1945. Przyczyn tego stanu rzeczy może być kilka, ale z pewnością należy pamiętać o tym, że przez ponad pięć okupacyjnych lat tajne nauczanie nie mogło w żaden sposób zastąpić regularnej edukacji. Dlatego też analizowane teksty tak bardzo różnią się swoją formą, choć tematyka jest podobna. W tym właśnie sensie należy mówić o głosie pokolenia, które wspólnie doświadczyło okrucieństwa wojny i doznało podobnych krzywd, ale mówiło o tym w różnorodny sposób, gdy weźmiemy pod uwagę jakość formalną wypracowania.

W korpusie wypracowań z Wielkopolski i Kielecczyzny można wyróżnić powtarzające się motywy, które podaję w porządku częstotliwości pojawiania się w uczniowskich tekstach:

1. Aresztowanie i wywózka ojca (bądź innego bliskiego krewnego) do obozu, tęsknota i oczekiwanie na jego powrót.

2. Zemsta (np. masowe egzekucje, palenie domów lub stodół wraz z ludźmi) żołnierzy niemieckich na grupie mieszkańców za pomoc partyzantom.

3. Przypadkowy udział w aktach wojennego terroru, jak rozstrzeliwanie, wieszanie, łapanka, palenie ludzi obwinionych o współpracę z partyzantami, publiczne tortury.

4. Obraz niezłomnego, walecznego partyzanta (niekiedy pojawia się nazwa reprezentowanej przez niego organizacji, np. AK, BCh).

5. Tajne nauczanie i szlachetna postawa nauczyciela, szerzej inteligencji.

6. Głód. 
7. Powstanie warszawskie jako symbol oporu Polaków wobec bestialstwa nazistów9

8. Przymusowa praca fizyczna (np. kopanie okopów, zbieranie płodów rolnych) po zajęciach szkolnych (dotyczy to wypracowań z wielkopolskich szkół).

9. Przemoc nauczycieli niemieckich wobec polskich uczniów (dotyczy to wypracowań z wielkopolskich szkół).

10. Rosjanie i Armia Czerwona jako wyzwoliciele.

11. Obraz złego Polaka kolaborującego z nazistami.

Należy również wspomnieć o ekspresji i silnych emocjach, które obecne są niemal we wszystkich tekstach pisanych zarówno przez uczniów ze szkół z Wielkopolski, jak i Kielecczyzny. Szczególnie autorzy wypracowań sygnowanych tytułem „Co mówią nam zbiorowe mogiły?” eksponowali z jednej strony żal za zabitymi żołnierzami i cywilami, z drugiej zaś stałym elementem ich wypowiedzi była zwerbalizowana nienawiść do „barbarzyńskich Niemców”, niekiedy nazywanych także „dzikimi Niemcami”. Pierwsze z określeń na tyle często pojawia się w tekstach dzieci, że należy uznać je za rodzaj wspólnotowej oceny czy wyrażenia idiomatycznego bardzo mocno związanego nie tylko z nazistami, ale w ogóle z Niemcami. Autorka „Moich wspomnień zbrodni niemieckiej” w następujący sposób - typowy dla wielu wypracowań - rozpoczyna swoją opowieść o tragicznych doświadczeniach związanych z Wołyniem: „Nie ma takiego człowieka w Polsce, który nie miał jakiegoś wspomnienia z czasów okrutnych zbrodni niemieckich. Każde małe dziecko dobrze zna Niemca i jego sprawki. Ja mam bardzo dużo wspomnień z czasów okupacji, a chcąc to wszystko opisać, nie miałbym na tyle papieru" ${ }^{10}$. Obok negatywnych emocji, także formułowanych pod adresem Ukraińców, bardzo dużo wypracowań - szczególnie pisanych przez uczniów wiejskich szkół - kończy się wprost wyrażoną deklaracją miłości do wolnej, chociaż „umęczonej” ojczyzny: „Polacy znosili wszystkie owe męki i trudy dumnie i wytrwale, i ducha polskości nikt nie był w stanie im wydrzeć. Gorąca miłość do Ojczyzny pozwoliła nam przenieść wszystko co najstraszniejsze i najokrutniejsze. Pozwoliła doczekać tej chwili, kiedy możemy oddychać pełną piersią wolnością"11.

Kilkudziesięcioro uczniów z Okręgu Szkolnego Kieleckiego przygotowało rysunki, których tematem jest przede wszystkim codzienność okupacyjna. Jak wolno sądzić, także i one były efektem działań władz oświatowych, a nie spontaniczną reakcją młodych ludzi. Niezależnie od okoliczności ich sporządzenia na uwagę zasługują daleko posunięty realizm oraz ekspresja rysunków, nawet tych, w których autorzy nie posługiwali się kolorowymi kredkami. Traktuję je jako uzupełnienie wypracowań w tym sensie, że odsłaniają nie tylko okupacyjny koszmar, ale również głębię przeżyć i doświadczeń młodych ludzi. Nie na wszystkich pracach plastycznych zachowało się imię i nazwisko autorki bądź autora. W związku z tym, że materiał ten pełni funkcję dodatku do wypracowań, nie poddałem go odrębnej analizie.

${ }^{9}$ Wśród wielu wypracowań szkolnych, w których wspomina się o powstaniu warszawskim jako akcie symbolicznego oporu i zwycięstwa Polaków nad Niemcami, zwraca uwage jeden, bardzo obszerny tekst uczennicy klasy szóstej z Publicznej Szkoły Powszechnej im. A. Dygasińskiego w Kielcach; Archiwum Państwowe w Kielcach. Wypracowania szkolne uczniów szkół kieleckich na temat okupacji 1946. Inspektorat Szkolny Kielecki 1945-1950. 21/322, k. 2-8. Wypracowanie zostało oparte na dwóch motywach - na opisie tęsknoty za walczącym w powstaniu ojcem i obrazach walk żołnierzy AK z Niemcami.

${ }^{10} \mathrm{~K}$. Góralówna, Moje wspomnienia zbrodni niemieckich, Wypracowania szkolne uczniów szkół kieleckich na temat okupacji 1946. Inspektorat Szkolny Kielecki 1945-1950. 21/322, k. 14

${ }^{11} \mathrm{Cz}$. Brudek, Wspomnienie zbrodni niemieckiej, Wypracowania uczniów szkół powszechnych o tematyce okupacyjnej z terenu powiatu sandomierskiego 1946 r. Kuratorium Okręgu Szkolnego. 21/321, k. 147. 


\section{Teksty wypracowań szkolnych (wybór)*}

\section{1.}

Okupanci Polski nietylko gnębili Polaków, ale nie pozwolili się uczyć. W niektórych wsiach i miastach były szkoły, a w innych nie było szkół. znowu w innych szkołach ściągali przymusowo i uczyli wszystko w języku niemieckim. Kazali się modlić po niemiecku, a którzy nie chcieli [tego wykonywać - dopisek prawd. nauczyciela] okrutnie bili. Gdzie się znalazła polska szkoła, tam nie wolno było uczyć geografii, historii Polski i nie wolno było nawet mówić o Polsce. Nauczyciele i profesorowie przebierali się za rolników, bo Niemcy zabierali [ich - dopisek prawd. nauczyciela] do obozów. Szli na wsie i gdzieś w ukryciu uczyli dzieci. Szkół wyższych wogóle nie było. Młodzież uczyła się tajnie, nie chcąc tracić czasu. Niemcy śledzili tajne nauczanie i gdy wyśledzili, nauczyciela zabierali do obozów, a dzieci mordowali i zabijali ${ }^{12}$.

2.

\author{
Były to \\ straszne rządy, \\ krwią i żelazem \\ pisane
}

Niemcy bardzo szybko zdobywali ziemie polskie i zaraz na zdobytych terenach wprowadzali swoje rządy. Były to straszne rządy, krwią i żelazem pisane. Tutaj wymordowanie i niszczenie ludności polskiej a w szczególności inteligencji było hasłem rządu niemieckiego. W tym celu wykreślono z programu szkół powszechnych naukę historii i geografii polskiej, zabroniono śpiewać piosenki patriotyczne, zabrano biblioteki jej obrazy historyczne. [...] Jednak Polacy za żadną cenę nie dali się wynarodowić, a dzieci polskie patrząc na bezprzykładne męczeństwo ojców i braci postanowiły stanąć do walki z wrogiem i uczyć się tajnie. Toteż idąc na komplety musiały chować książki pod płaszczyki albo też pod bluzki. Idąc ulicą badały ostrożnie, czy gdzieś na rogu ulicy nie stoi żandarm niemiecki. W takim położeniu znajdowałam się i ja i cztery moje koleżanki. Chodziłyśmy na tajne lekcje do jednego pana nauczyciela. Lekcje odbywały się 3 razy w tygodniu o godzinie 4 po południu. Naszym umówionym hasłem było słowo: książka. W nauce robiłyśmy średnie postępy, przerabiałyśmy piątą klasę szkoły powszechnej. Przez cały rok nauki raz tylko przydarzyło nam się nieszczęście. Gdy uczyłyśmy się historii, wszedł do mieszkania żandarm. My widząc go przez okno, zaraz schowałyśmy książki wysoko na piec kaflowy, a same zabawiłyśmy się w ciuciu-babkę. Żandarm zrewidował mieszkanie i wyszedł, a my nadal uczyłyśmy się historii. Przez ten rok tajnego nauczania dojrzałam duchowo, stałam się mężniejszą i odważniejszą, Zrozumiałam co to znaczy wojna i co to jest niewola, a nawet gotowa jestem oddać swe życie za Polskę ${ }^{13}$.

We wszystkich wypracowaniach zachowałem pisownię oryginalna.

12 Z. Ziółkowska, Temat II. Wspomnienia z tajnego nauczania, Wypracowania uczniów szkół powszechnych o tematyce okupacyjnej z terenu powiatu sandomierskiego, 1946 r., 21/231. Archiwum Państwowe w Kielcach, k. 137.

${ }^{13}$ A. Gawlik, Moje wspomnienia tajnego nauczania, Wypracowania szkolne uczniów szkół kieleckich na temat okupacji, 1946. Inspektorat Szkolny Kielecki 1945-1950, 21/322. Archiwum Państwowe w Kielcach, k. 27-28. 
3.

Wszyscy wiedzieli, co nas może spotkać po takiej walce. Nagle nad lasem ukazały się kłęby czarnego dymu. Zrozumieliśmy wszyscy, co to znaczy. Michniów płonął. Szczegóły nieznane. Ale to było pewne, że palił się Michniów. Zdawało się wszystkim, że za chwilę nas to spotka. Ludzie chodzili smutni, kobiety, dzieci płakały. A to było najstraszniejsze, że nikt z nas nie mógł ginącym dopomóc. Przeżywaliśmy straszne chwile niepewności i oczekiwania. Po południu doszła nas wiadomość, że gestapo niemieckie aresztowało wszystką młodzież Michniowa, którą wywieziono samochodami w nieznanym kierunku. A ludzie, którzy nie zdążyli uciec w sąsiednie lasy żywce spalili w ich własnych domach. Wieczorem ocalała resztka ludności Michniowa schroniła się do naszej wioski. Mówić nie mogli z przerażenia. W całej wsi nie pozostał ani jeden dom, ani jedna stodoła. Sterczały tylko kominy i szkielety opalonych drzew, które poruszane wiatrem śpiewały pieśni żałobne za konających. Wiadomość ta zmroziła serca wszystkich Polaków w Suchedniowie ${ }^{14}$.

4.

W czasie okupacji niemieckiej byłam w Warszawie. Dnia 25 XI 39 r. rozpoczęło się bombardowanie Warszawy ${ }^{15}$. Ludzie z wielkim pośpiechu uciekali do schronu, bomby padały jedna za drugą. Ja z rodzicami i z rodzeństwem siedziałam w schronie. Nagle wstrząs, kurz aż cały dom się zakołysał. Kto następny dom uderzyła bomba. Gruzy się posypały, ludzie uciekali na oślep, dzieci z piskiem i krzykiem tuliły się do matek. Takie bombardowanie trwało $5 \mathrm{dni}$. Po nich rozpoczęła się ciężka okupacja niemiecka. Po tych pięciu dniach ludzie zmęczeni, a czasem i chorzy wychodzili ze schronów. Jak wyszliśmy na miasto to wszędzie były zburzone lub spalone domy, ludzie ubolewali nad spalonym miastem. Te pięć lat spędziliśmy pod okupacją niemiecką. Ale wolno nam było mówić po polsku i chodzić do Polski szkoły, lecz niemcy nie pozwolili uczyć się geografii ani też historii polski. Niemcy szaleli i po całym mieście. Codziennie rozstrzeliwali kilkadziesiąt niewinnych ludzi. Aż nareszcie skończyła się cierpliwość polaków i dnia 1e sierpnia 1945 o godzinie piątej wybuchło powstanie z trudem przygotowywane od czterech lat. Nasi rzołnierze mężni walczyli o wolność ukochanej Warszawy. Niemcy mając samoloty granatniki ryczące krowy (miotacze min) i.t.p. dzień po dniu zdobywali i palili ulice za ulicą. Cała Warszawa była w płomieniach, a niemcy ze zdobytych ulic, ludzi wysyłali do niemiec, albo do innych miast i wsi. Lecz Warszawa mężnie się broniła choć pozostały z niej tylko gruzy i dopiero dnia 3 października poddała się. Podczas powstania siedzieliśmy w schronie aż do dnia piątego września 1944 roku w którym niemcy wywieźli nas do obozu przejściowego w Pruszkowie, a stamtąd na wioskę, pięćdziesiąt kilometrów od Warszawy. I tam przeżyłam jeszcze pięć miesięcy pod okupacją niemiecką, aż nadszedł dzień oswobodzenia nas od niemców. Z wielką radością przyjmowaliśmy wojska a zwy-

${ }^{14}$ Z. Garbalówna, Moje wspomnienia zbrodni niemieckich, Wypracowania szkolne o tematyce okupacyjnej uczniów ze szkoły w Suchedniowie, 1946. Inspektorat Szkolny Kielecki, 1945-1950, 21/322. Archiwum Państwowe w Kielcach, k. 17-18.

${ }^{15}$ Błędna data; bombardowanie Warszawy trwało od 1 do 27 września 1945 roku.

Sztuka Edycji 2/2020 
cięskie i dziękowaliśmy Bogu że nareszcie nadszedł dzień pokonania największego wroga niemca. Który przez pięć lat panoszył się na ziemiach polski ${ }^{16}$.

\section{5.}

Wracamy z wakacji i ku naszemu zdumieniu dowiadujemy się że wojna i tego samego dnia bombardowanie. Uciekać do schronów, wychodzić coś zjeść i znów krzyk - słychać samoloty. Za chwilę odzywa się ogromny huk wybuchów. A za kilka dni rozchodzi się wieści jeszcze groźniejsza - Niemcy wchodzą do Poznania! A przedtem huk wysadzanych mostów na Warce. Wszystko to przyjmowało mnie grozą. W tydzień potem aresztowali mi tatusia i zawieźli na Młyńską. Jak tatuś był w więzieniu u nas była rewizja w mieszkaniu i Niemcy przetrząsali całe mieszkanie. Po dwóch tygodniach tatusia wypuścili. W listopadzie wysiedlili nas na Główną do baraków. Stamtąd do Częstochowy. W Częstochowie byłem na Jasnej Górze wiele razy. Później tatuś dostał posadę w majątku Raczyńskich w Złotym Potoku. Jako fachowiec prowadził sztuczną wylęgarnie pstrągów. Pstrągarnia leżała 4 km od wsi Złoty Potok. Okolica była śliczna, ostre stoki górskie pokryte piętrzącymi się skałami wapiennymi na których były jeszcze ślady morza w postaci skamieniałych muszli. To wszystko pokryty zielenią bukowego starego lasu. Odwiedzali nas niejednokrotnie partyzańci. Kilka razy wykonywali napady na żandarmów jadących zabierać chłopów bydło, lub na urzędników niemieckich z urzędu pracy. Cztery razy odbyło się to niedaleko naszego domu i potem baliśmy się represji. Były to dni denerwującego wykrzykiwania. Lecz kończyło się na obławie, która zawsze spełzła na niczym. Uczyli mnie rodzice w domu, bo szkoły nie było w pobliżu. Ale mimo to miałem dużo czasu. Siedziałem prawie cały dzień w lesie zbierając: grzyby, jagody i zioła. Obcowałem bardzo dużo z przyrodą i zwierzętami: leśnymi, wodnymi i ptactwem. W zimie jeździłem na nartach, łyżwach i sankach. I tak przeszło mi pięć lat. I teraz kiedy Niemców już wykurzyli wróciliśmy do Poznania.

Ja nigdy nie wątpiłem że Polska zmartwychwstanie lecz zawsze wierzyłem że zajaśnieje jeszcze większą uchwałą niż z przyszłości.

Ładnie wyraziłeś swoje przeżycie w okresie okupacji. Bardzo dobrze [komentarz nauczyciela]. 25 maja 1945 r. ${ }^{17}$

6.

Wiadomość o wojnie odbiła się szerokim echem po całym świecie. Polska młoda istniejąca zaledwie lat dwadzieścia nie mogła wytrzymać nawały wroga który szybkim krokiem wkraczał w nasz kraj. strach przed wrogiem zapanował w całej Polsce. Tłumy uchodźców ciągnęły z zachodu na wschód i po drodze zabierali masy innych. Do tych przyłączyliśmy się i my. Byliśmy ewakuowani, aż na Wołyń, gdzie widzieliśmy wkracza-

${ }^{16}$ E. Marciniak, Moje przeżycia z czasów okupacji niemieckiej, Wspomnienia młodzieży wielkopolskiej z lat okupacji niemieckiej 1939-1945. Archiwum Instytutu Zachodniego w Poznaniu, k. 28-31, IZ, Dok.II-402.

${ }^{7}$ A. Ichechtel, Moje przeżycia w okresie okupacji. Rok 1939, Wspomnienia młodzieży wielkopolskiej z lat okupacji niemieckiej 1939-1945. Archiwum Instytutu Zachodniego w Poznaniu, k. 36-37, IZ, Dok.II-402. 
jącą w 1939 r. na ziemie polskie Armię Czerwoną. Rozpoczęła się okupacja - niewola. Do domu z ewakuacji wróciliśmy w listopadzie. W początkach okupacji nie rozumiałam jeszcze słowa niewola. Nie zdawałam sobie sprawy co to jest wojna, mimo że matka i brat opłakiwali utratę ojca, który gdzieś zginął bez żadnych wiadomości. Dopiero później zrozumiałam, czym jest Niemiec dla Polaka. Wtedy tak, jak matka i brat pędzili życie w niepewności o jutro zaczęłam pędzić i ja. Wtedy odczułam już pierwsze złapanie brata do robót w Niemczech, mimo że brata nie zabrali bo był jeszcze za młody. Bardziej utkwiły mi w pamięci czasy ostatnie t.j. r. 1943 i 1944. Głęboko wryła mi się w pamięć chwila kiedy Niemcy zabrali matkę do obozu karnego. Myśleliśmy z bratem, że zostaniemy już sierotami, bez ojca i matki, lecz dzięki trudom dobrych ludzi, którzy zaczęli się starać o matkę, ponieważ my byliśmy bezsilni, matka po miesiącu wróciła do domu. Ludzie żyli nadzieją. Spodziewali się, że każde jutro przyniesie zmianę. Wolność Ojczyzny. Każdy udany czyn partyzantów uderzał radosnym odgłosem w me serce jak i w serca innych rodaków, lecz strata chociażby jednego syna Ojczyzny, przesłaniała ten promyk radosny i przynosiła na chwile zwątpienie. Mimo, że wróg gnębił i ścigał naszą młodzież ukochaną, to wtedy po lasach tworzyła zbrojne organizacje i założyła kamień węgielny pod nową Polskę. $Z$ dumą i radością na twarzy patrzyłam niekiedy na tych obdartych i wynędzniałych, lecz tak dzielnych. Wieść o posuwaniu się wojsk radzieckich i wieść o klęskach niemieckich na frontach zachodnich i wschodnich podniosła na duchu Polaków. Niemcy mając zamiar stawiać opór wojskom radzieckim w Polsce nad Nidą postanowili kopać okopy. Znów rozpoczęły się łapanki. Złapanie brata i pożegnanie z nim wryło mi się w pamięć, a potem tak radosne powitanie go, ponieważ uciekł Niemcom i wrócił do domu, a okopów nie kopał. Pamiętam również, jak w ostatnich miesiącach, tygodniach, a nawet dwóch przed wypędzeniem okupanta brat z kolegami musiał się ukrywać po ziemiankach, stodołach i innych kryjówkach. Serce mnię nieraz bolało jak widziałam brata zziębniętego, mokrego, kiedy wrócił z lasu, z pracy i musiał iść spać do kryjówki. Trudno, musiał cierpieć, a z nim matka i ja, ponieważ chciał być w Polsce i chciał być razem z nami. Na odgłos huków armatnich zabiły nam serca. Wieść o planie wkroczenia Armii Czerwonej do Kielc rozbiegła się szybko po okolicy. Widziałam teraz jak ta niegdyś zdawałoby się niezwyciężona armia Hitlera złamana cofała się w nieładzie i niedostatku. Niejeden Niemiec prosił chleba, niejeden prosił o łaskę, lecz Polacy którzy tyle krzywdy odczuli od okupanta, nie mieli nad nimi litości. Wreszcie wkroczenie wojsk o bój o Niewachlów, pożar, wiele trupów. A później po raz pierwszy po sześciu latach niewoli Hymn „Jeszcze Polska nie zginęła” i Roty wryło mi się głęboko w mą pamięć. Wtedy byliśmy już szczęśliwi, ponieważ byliśmy wolni w wolnej Polsce ${ }^{18}$.

\section{7.}

Niedaleko od nas jest wieś Baranów, która należy do gminy Suchedniów. Za tą wsią jest wysoka góra pokryta lasem. Tam to właśnie Niemcy często przywozili swe ofiary i zabijali je ${ }^{19}$. Pewnego dnia przywieźli 18 mężczyzn tylko w bieliźnie. Wszyscy mieli

${ }^{18}$ A. Pawełczyk, Moje wspomnienie zbrodni niemieckich, Archiwum Państwowe w Kielcach. Inspektorat Szkolny Kielecki. Wypracowania szkolne o tematyce okupacyjnej uczniów ze szkół w Bobrzy, Niewachlowie, Zagnańsku, k. 32-34.

${ }^{19}$ Opis odnosi się do jednej z wielu akcji odwetowych nazistów na ludności cywilnej, która udzielała różnej pomocy oddziałom partyzanckim. W Baranowie naziści dwukrotnie dokonywali pacyfikacji i rozstrzeliwali mieszkańców.
W początkach okupacji nie rozumiałam jeszcze słowa niewola 
związane powrozami nogi. Ludziom tym kazali najpierw wykopać sobie wspólny grób, gdyż za chwilę miała nastąpić egzekucja. Kiedy groby były już gotowe, Niemcy przyprowadzali ich dwójkami nad grób i zabijali, strzelając z tyłu w głowy. Pozostali czekali na swoją kolej. Jednemu z tych mężczyzn z ostatniej dwójki udało się uwolnić nogi. kiedy go prowadzono nad grób, popędził w las. Posypały się za nim strzały, ale żadna go nie dosięgnęła. Biegł, ile miał w sobie sił, a sił dodawała mu śmiertelna trwoga. Około 2 dni był na drzewie, lecz go nie złapali. Był lekko ranny. Trzeciego dnia przyszedł do naszej wioski, dostał ubranie i poszedł do swojego domu. Za kilka miesięcy przyszedt, aby zobaczyć to miejsce, gdzie miał taką przygodę. Podrodze wstąpił do nas i opowiadał nam to swoje przeżycie. Był to znajomy tatusia. Nazywał się Szymon Kieraga z powiatu iłżeckiego ${ }^{20}$.

8.

Zbiorowe mogiły przypominają nam dużą ilość pomordowanych Polaków w okropny sposób przez Niemców. W 1943 r. ze Skrzypaczewic ${ }^{21}$ zabili jednego Niemca, więc Niemcy przywieźli 47 Polaków do Koprzywnicy powiązali im ręce i postawili pod murem. Polacy wiedzieli że będą zabici więc krzyczęli strasznie i wołali o pomoc do ludzi i Boga, prosili o cud nikt im jednak nie mógł pomóc ${ }^{22}$. Niemcy dali rozkaz, aby ludzie nie wychodzili z domów ale daleko było słychać krzyki i jęki rozstrzeliwanych Polaków a nawet i dzieci, Niemcy nieubłagani byli i wystrzelali wszystkich. A jeden chłopiec czternastoletni zaczął uciekać, choć miał związane ręce, uleciał może 20 metrów lecz kule zanim sypały się, jak grad (więc) zginąć musiał. Krew z Polaków rozlała po ulicy i płynęła jak strumień. Wszystkie ciała pochowano w jednej mogile. Takich mogił z Polaków spotykamy bardzo dużo co są w straszny sposób zamordowani. Niedaleko od nas są Łyczoki ${ }^{23}$, w mały lasek często Niemcy zajeżdżali w nocy, a czasami w dzień z Polakami. Kazali im kopać później wchodzić do nich a potem strzelali w nich. Niektórzy byli zabici a inni byli ranni wszystkich zasypali ziemią.

My Polacy tego nigdy nie zapomnimy co Niemcy złego u nas zrobili ${ }^{24}$.

9.

Kiedy Niemcy zaczęli się u nas w Polsce gospodarzyć zaraz wprowadzili nowy program nauki. Zabraniali nam się uczyć historii, geografi, korzystać z naszych polskich książek. Wydali zarządzenie do kierownictw wszystkich szkół by dzieciom odebrali książki. $\mathrm{Na}$ ich miejsce wprowadzili przez siebie wydane Stery na wzór dawnych Płomyczków. Każdy wychowawca dawał do zrozumienia swoim uczniom by książek do szkoły nie przynosili nie oddawali. Rodzicom którym zależało na wychowaniu swego dziecka w duchu polskim posyłali je na tajne nauki. Nauczycielstwo widząc potrzebę wychowa-

${ }^{20}$ B. Karaś, Chwila najbardziej pamiętna z lat okupacji, Państwowe Archiwum w Kielcach. Inspektorat Szkolny Kielecki, 1945 -1950. Wypracowania szkolne o tematyce okupacyjnej uczniów ze szkoły w Masłowie, 1946, k. 44-45.

${ }_{21}$ Powinno być: Skrzypaczowic.

${ }^{22}$ Nie udało się ustalić szczegółowych informacji na temat opisanego przez ucznia zdarzenia.

${ }^{23}$ Regionalna nazwa porośniętych trawą nieużytków.

${ }^{24} \mathrm{~J}$. Kwiecień, O czym mówią zbiorowe mogiły z czasów okupacji niemieckiej, Archiwum Państwowe w Kielcach. Wypracowania uczniów szkół powszechnych o tematyce okupacyjnej z terenu powiatu sandomierskiego, 1946, k. 15-16. 
nia młodzieży w duchu polskim ofiarowało swoje usługi. Nie zwracając uwagi na grożące niebezpieczeństwo ze strony władz niemieckich. młodzież uczęszczająca kryła się ze swoją nauką by nie narazić nauczycielki na utratę życia. Mimo ostrożności zachowywanej szpiegom niemieckim nieraz udało się wykryć (wykryć) tajną szkołę. Nauczycielowi któremu udało się uciec musiał się kryć w lasach przed srogą karą. Niełatwa była nauka w czasie okupacji ${ }^{25}$.

10.

Nadszedł rok 1939, w którym Niemcy zajęli Polskę, aby pozostać w niej przez sześć długich, pełnych bolesnych przeżyć lat. Pierwszym krokiem Niemców wiodący do wytępienia poczucia narodowego Polaków było zamknięcie szkół i z bronienie uczenia się młodzieży polskiej. Pomylili się jednak Niemcy, bowiem dzieci, wierne swej Ojczyźnie, nie bacząc na grożące im niebezpieczeństwa, ze strony okupanta, nie zapomniały mowy i historii polskiej. Przez wszystkie lata wojny uczono się potajemnie ze starych, przedwojennych podręczników, które noszono głęboko ukryte pod płaszczami, lub w kieszeniach. Książki te przechowywano z wielką starannością, strzegąc przed bacznymi oczyma Niemców. Pierwsze wspomnienie z czasów tajnego nauczania głęboko zaryło mi się w pamięci. Pamiętam dzień wiosenny, majowy. Kwitty bzy, a czeremcha opadała na ścieżki w wilgotnych, białych kiściach, rozsiewając upajające dzwonię. Dochodziła druga po południu. Cienistą alejką ogrodu zmierzałam w stronę naszej nauczycielki, gdzie się miały odbyć lekcje. Pod płaszczem miałam książkę polską i geografię, a resztę książek i zeszyty zwinięte w rulonie pakunkowego papieru. Gdy wyszłam na szosę, ujrzałam stojące auto, z którego wysiadali Niemcy. Serce poczęło mi bić gwałtownie - poznałam gestapowców. Trupie czaszki lśniły złowrogo w blaskach słońca. Zatrzymałam się. Co robić? - przemknęła mi przez głowę myśl Wrócić się czy iść dalej? Postanowiłam dla niewzbudzenia podejrzeń iść przed siebie śmiało, nagle z furtki wiodącej do domu mej nauczycielki wyszło kilku Niemców, prowadzących między sobą naszą panią. Zdrętwiałam z przerażenia. Głośne przekleństwa ozwały się z okien domu w którym za chwilę miały odbyć się lekcje. Spojrzałam w nie i ujrzałam wyrzucone rękoma żandarmów książki, pióro i zeszyty. Silny pot wystąpią mi na czoło. Do bijącego serca przycisnęłam dłonie i stanęłam, oparłszy się o płot. Niemcy tym czasem wsiedli do auta i odjechali. Warkot samochodu długo dał się słyszeć, aż umilkł zupełnie. O losie biednej kochanej pani nauczycielki nic więcej nie dowiedziałam się. Wraz z przybyłymi na miejsce wypadku uczennicami i uczniami rozeszliśmy się do domów z dziwnym nieutulonym smutkiem ${ }^{26}$.

${ }^{25}$ M. Kosowicz, Wspomnienia z tajnego nauczania, Archiwum Państwowe w Kielcach. Wypracowania uczniów szkół powszechnych o tematyce okupacyjnej z terenu powiatu sandomierskiego, 1946, k. 203-204.

${ }^{26}$ W. Łukowska, Wspomnienie z tajnego nauczania, Archiwum Państwowe w Kielcach. Wypracowania uczniów szkół powszechnych o tematyce okupacyjnej z terenu powiatu sandomierskiego, 1946, k. 278. 
W naszym domu mieszkał stróż Molęda i miał syna Kazimierza. Kazimierz miał karabin. Raz Kazimierz manipulując coś przy karabinie, zabił swoją siostrę. Rodzice wezwali doktora, a doktór zeznał, że ona zabita z karabinu. Doktór zatelefonował do policji. Przyjechała policja i zrobili rewizję, ale broni nie znaleźli, tylko znaleźli kulka wystrzelono, która zabiła siostrę na śmierć. Zaraz policja zabrała ojca, matkę, i braci zabrali ich do żandarmerii niemieckiej. Na trzeci dzień przyjechało bardzo dużo żandarmerii. Okrążyli całą wioskę. Rodzina Molędów powydawała bardzo dużo ludzi. Żandarmi chodzili z listą i wyciągali ludzi z mieszkań. Okropnie bili, i zakładali kajdany na ręce. Przepędzili pod gminę i tam musieli leżyć na twarzach. Gdy wszystkich już rozpędzali, zaczęli badać i okropnie bić. Wszystkich zbadali i nikogo nie zwolnili. Spędzili paru chłopów do kopania grobu. Tych aresztowanych tak okropnie bili, nogi i ręce im poprzetrącali, zęby po wybijali. Po paru godzinach zaprowadzili ich do grobu, nastawili karabin maszynowy i wszystkich potem ludzi pozwłóczyli i pokładali do grobu. Zasypali grób później. Po kilku miesiącach zjechała żandarmeria niemiecka i spaliła nieboszczyków prądem elektrycznym.

Policzna, 21 XI 1946 r. ${ }^{27}$

\section{2.}

Chwila najbardziej pamiętna dla mnie z lat okupacji jest następująca: Widziałam w 1939 roku na swoje oczy, jak Niemcy zawołali do siebie żydówkę z dzieckiem i kolbą to dziecko uderzył jeden z nich. Dziecko upadło z rąk i zabiło się. Żydówka zaraz zemdlała i potem Niemiec zastrzelił ją. A drugą chwilę mam taką w pamięci. Dziecko polskie szło przez miasto. Niemiec zawołał je do siebie i uderzył w policzek. Dziecko upadło na chodnik. Zabił je. Taki Szwab zabił niewinne dziecko polskie ${ }^{28}$.

\section{3.}

Podczas okupacji 1939 widziałem, jak Niemcy sprowadzili z całej wsi ludzi na ulicę i pytali ich, dlaczego nie wożą kloców. Tłumaczyli się ludzie, że nie mają koni ani wozów. Niemcy zaczęli ich psem szczuć i batem skórzanym bić29.

${ }^{27}$ W. Jędrówna, O czym mówią mogiły zbiorowe, Archiwum Państwowe w Kielcach. Inspektorat Szkolny Kielecki, 1945-1950. Wypracowania szkolne uczniów szkół kieleckich na temat okupacii, 1946, k. 96-98.

${ }^{28}$ S. Lachowska, Chwila najbardziej dla mnie pamiętna z lat okupacji, Inspektorat Szkolny Kielecki 1945-1950, $21 / 322$. Wypracowania szkolne o tematyce okupacyjnej ze szkoły w Dąbrowie, 1946, Państwowe Archiwum w Kielcach, k. 10.

${ }^{29}$ T. Kundera, Chwila najbardziej pamiętna dla mnie z lat okupacji, Państwowe Archiwum w Kielcach. Inspektorat Szkolny Kielecki, 1945-1950, k. 8 . 


\section{Rysunki* $^{*}$}

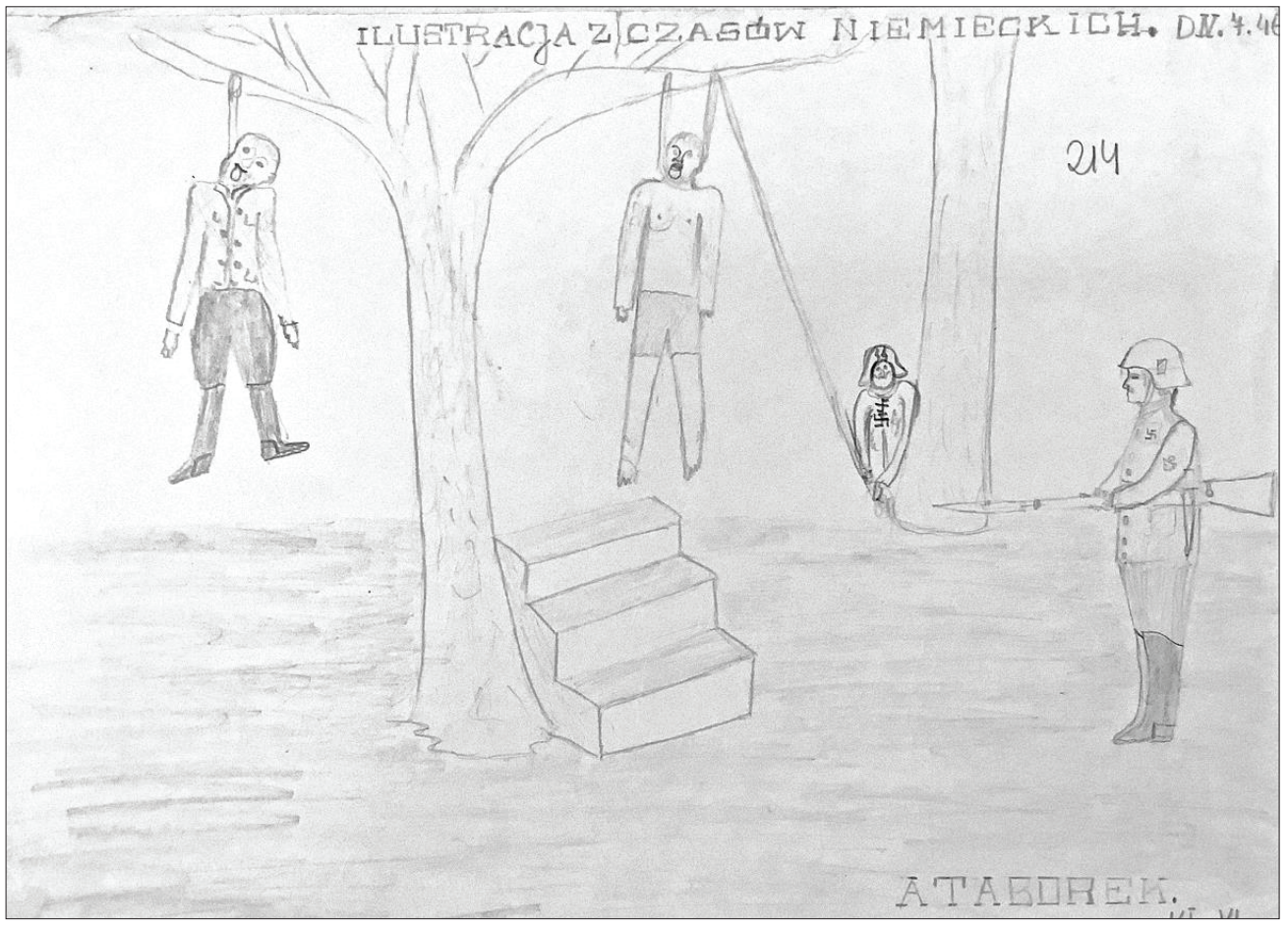

Il. 1. Rysunek ucznia Publicznej Szkoły Powszechnej w Żuradzie. Zbiory Archiwum Państwowego w Kielcach, sygn. $274 \mathrm{a} / 214$

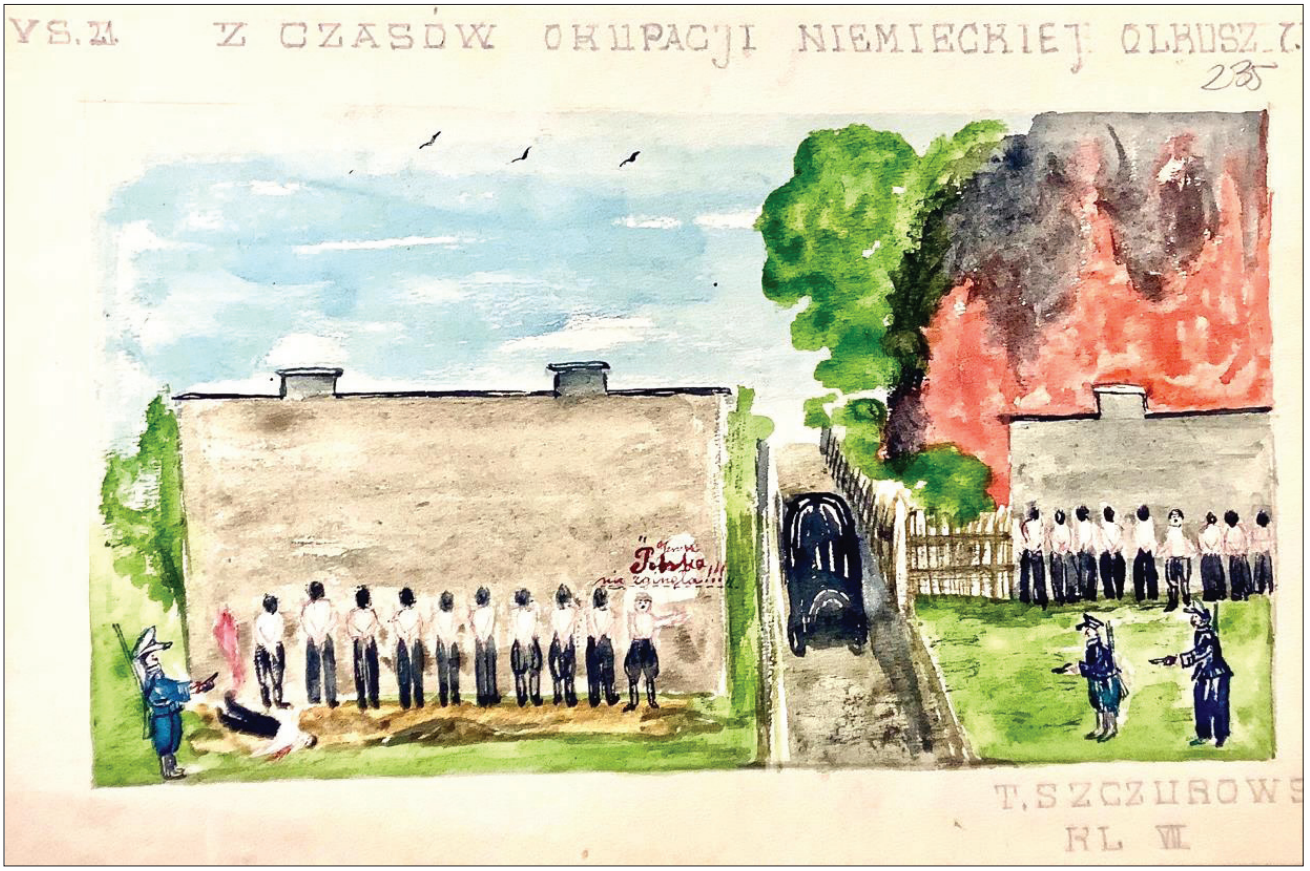

Il. 2. Rysunek ucznia Publicznej Szkoły Powszechnej w Żuradzie. Zbiory Archiwum Państwowego w Kielcach, sygn. 274a/235 


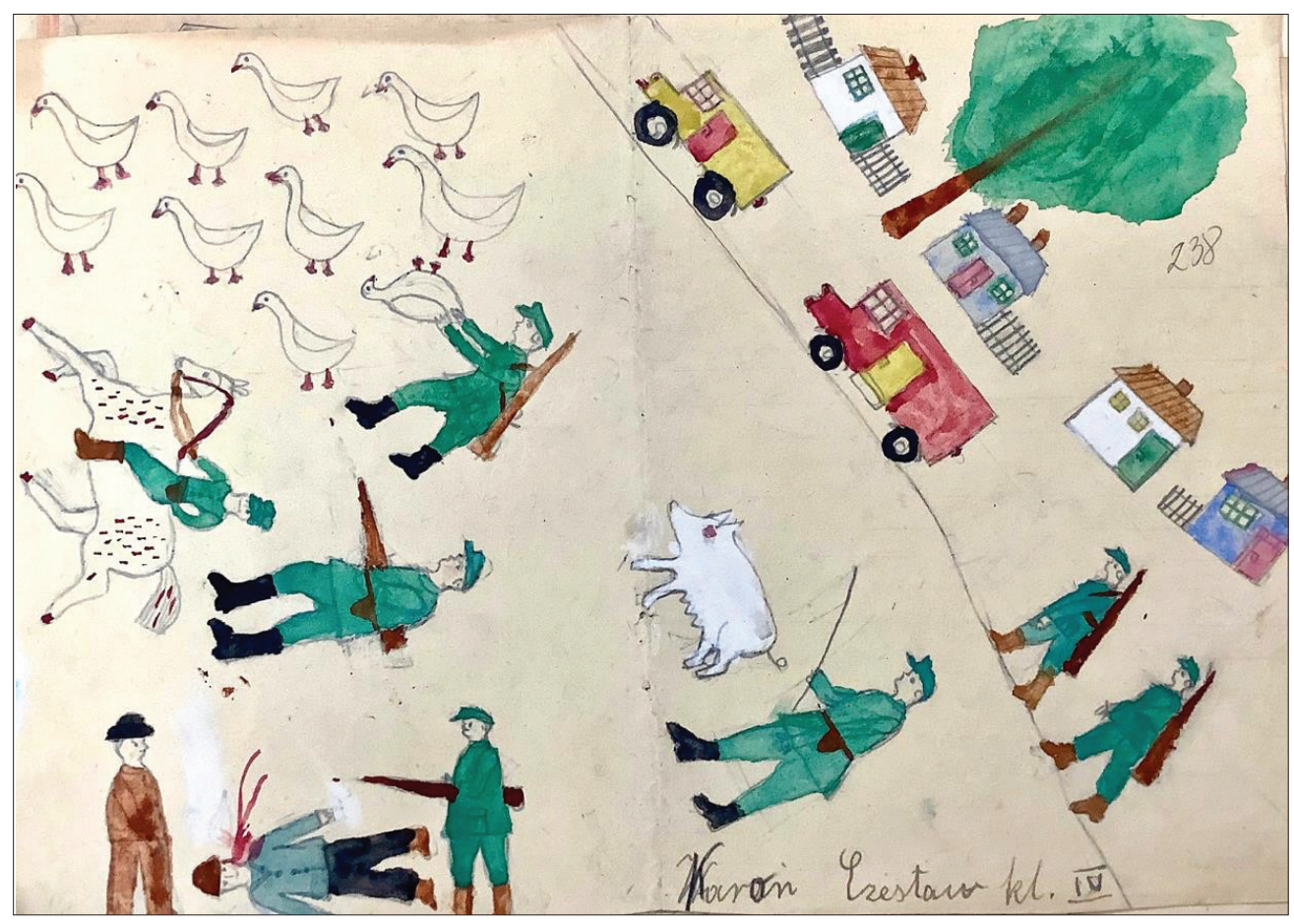

Il. 3. Rysunek ucznia Publicznej Szkoły Powszechnej w Żuradzie. Zbiory Archiwum Państwowego w Kielcach, sygn. 274a/238

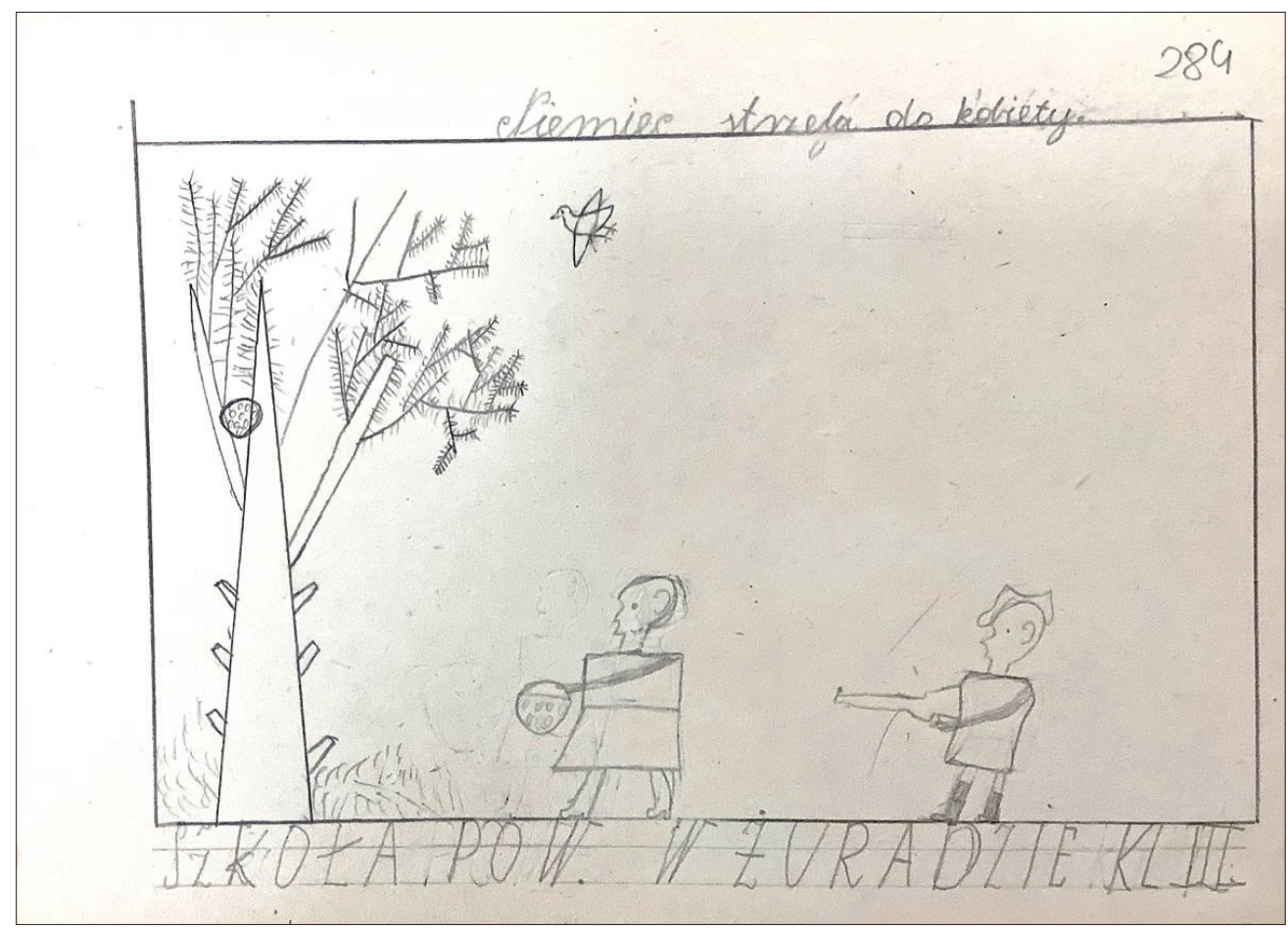

Il. 4. Rysunek ucznia Publicznej Szkoły Powszechnej w Żuradzie. Zbiory Archiwum Państwowego w Kielcach, sygn. $274 \mathrm{a} / 284$ 


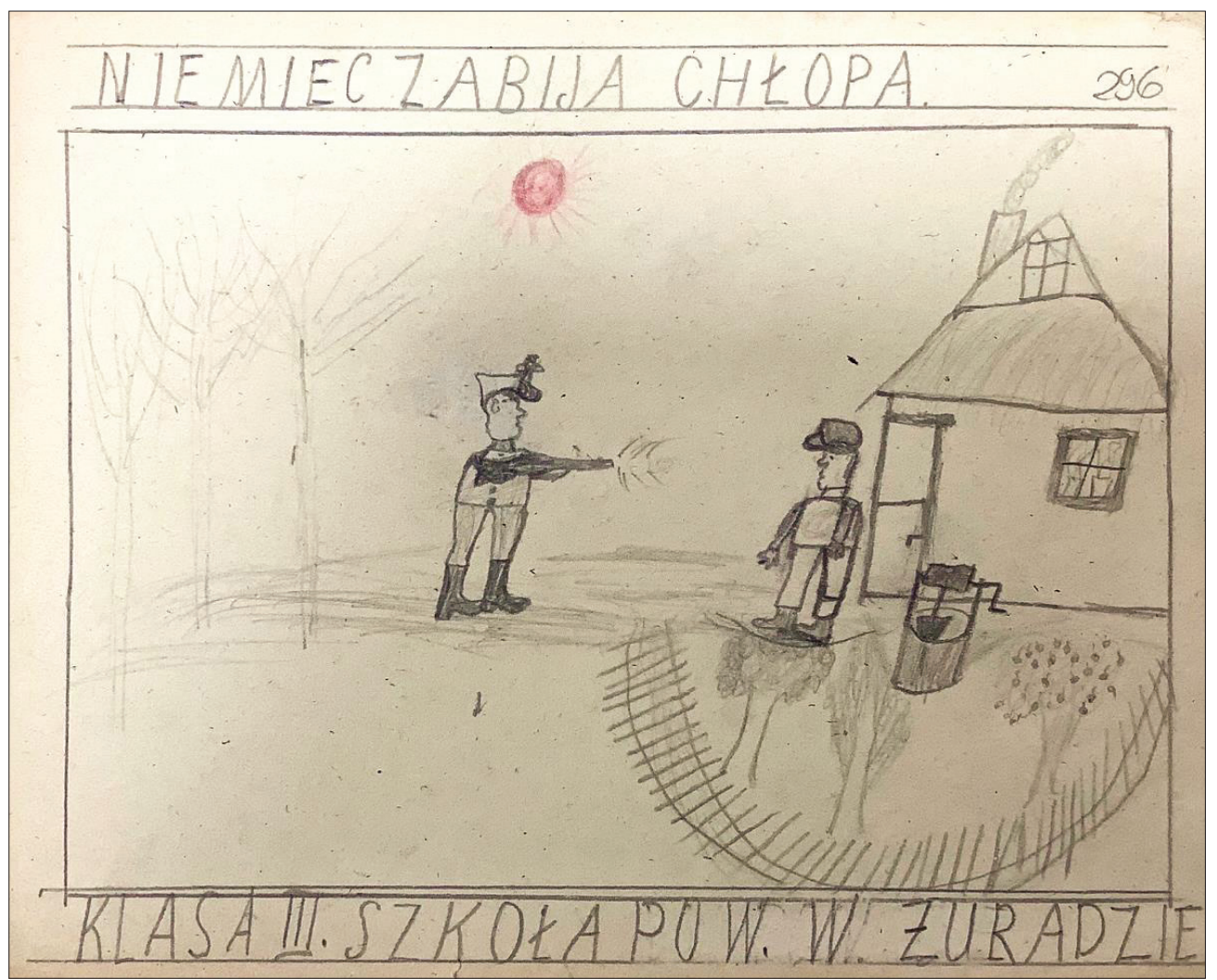

Il. 5. Rysunek ucznia Publicznej Szkoły Powszechnej w Żuradzie. Zbiory Archiwum Państwowego w Kielcach, sygn. $274 \mathrm{a} / 296$

Key Words: World War II, children's experience, war memories, children's works, children's illustrations

Abstract: The main goal of an article is to analyze the war memories which were written in 1945-1946 by young Poles (aged 10-16) from Kilecczyzna and also Warthegau (Warta’s Land) region. These children's works relate to the war atrocities, violence, and other kinds of war cruelty, with a part of the war memories depicting underground education, which was very popular during the WWII in Poland occupied by the Nazis. The children's memories and also their pictures are evidence or token of their traumatic experiences, which were demonstrated by the young authors in different ways. The analysis of these children's works based on the microhistory and also the bystander notion (Raul Hilberg). Thanks to these notions, the author of the article grasps the ways of the depictions of children's traumatic experiences, which focused on several following subjects: father's arresting, starvation, the Nazis' cruelty towards young and adult Poles, the picture of a brave guerrillas, Red Army's soldiers as liberators, and a secret education. 